\title{
JOURNAL.RU
}

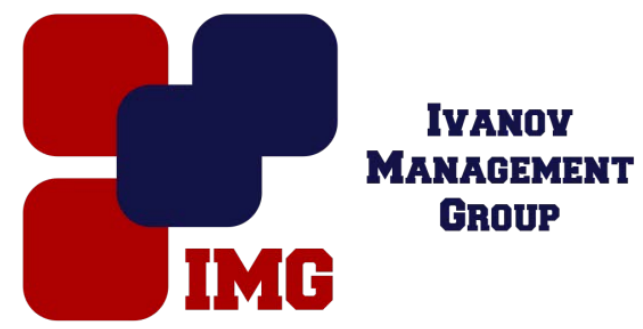

Мухамадиева Н.Н., Толымханова 3.Н., Амирханова Н. К., Казанцева А.Д. Государственный университет имени Шакарима Семей, Казахстан

doi: 10.18411/lj-28-02-2017-3-04

idsp 000001:lj-28-02-2017-3-04

\section{Лечение острого послеродового эндометрита}

\section{Аннотация}

В статье приведены результаты применения нового препарата Гонавет Вейкс для лечения острого послеродового эндометрита. Биотехнологическая карта эксперимента включает диагностику острого послеродового эндометрита, разрабатывание схем лечения с применением современных препаратов, результаты проведенных исследований с приведением клинических данных. Основным достижением при использовании предлагаемой схемы лечения ее кратковременность, эффективность и скорейшее возобновление воспроизводительной функции коров.

Ключевые слова: крупный рогатый скот, острый эндометрит, лечение,профилактика, бесплодие.

\section{Muchkamadieva N.N.., Tolimlhanova Z.N., Amirkhanova N.K., Kazantseva A.D.} Shakarym State University of Semey

Abstract Treatment of acute postpartum endometritis

The article presented the results of a new drug Gonavet Veyx for the treatment of acute postpartum endometritis. Biotechnology Experiment card includes the diagnosis of acute postpartum endometritis, developing treatment regimens with the use of modern drugs, the results of the research to bringing clinical data. The main achievement using the proposed scheme of its short duration of treatment, the efficacy and the early resumption of the reproductive function of cows.

Keywords: cattle, acute endometritis, treatment, prevention, infertility.

Современные сельскохозяйственные производители направляют все усилия на получение максимальной прибыли. По данным специалистов Министерства сельского хозяйства республики Казахстан ежегодно сельскохозяйственные предприятия недополучают около 20 телят от каждых 100 коров и до 20\% годового удоя от каждой бесплодной коровы, преждевременно выбраковывают более $35 \%$ коров и около $20 \%$ первотелок. Агропредприятия несут огромные 
экономические потери в результате снижения выхода телят, широкого распространения патологии родов и послеродового периода, увеличения бесплодия и яловости животных, продолжительности сервис-периода и межотельного периода, снижения уровня молочной продуктивности у проблемных коров. Экономические потери включают не только стоимость недополученных телят и молока, но и неоправданные затраты на кормление, содержание, уход и лечение проблемных коров, а также потери за счет преждевременной выбраковки высокоценных животных, которые можно предотвратить при экономически обоснованной организации работы по воспроизводству поголовья крупного рогатого скота. Актуальность проблемы продиктована необходимостью поиска способов лечения ранее не используемыми препаратами и внедрением в хозяйства. $[2,4]$

Целью настоящей работы являлось усовершенствование методов лечения острого эндометрита коров в послеродовой период, и установить эффективность применяемых препаратов с целью профилактики бесплодия крупного рогатого скота.

Maтериаль и методы. Экспериментальные и клинические исследования выполнены на основе методики планирования экспериментов способом создания опытных и контрольных групп коров по принципу аналогов. С целью оценки состояния органов половой системы использовали общепринятые в ветеринарии клинико-гинекологические методы исследования. Данное исследование проводилось в декабре 2015 года по ноябрь 2016 г. на базе Клиники ГУ имени Шакарима.

\section{Собственное исследование}

Материалом для исследования служили три коровы послеродового периода (одна корова казахской белоголовой с инвентарным номером KZ F1 89199650 и две красно-пестрой породы KZ F1 93697212/ KZ F1 95220815) в возрасте от 3 до 5 лет (декабрь, 2015г.), а также во время осмотра недавно отелившихся коров было зафиксированно три случая послеродовых заболеваний на 6 и 8 день после отела (в ноябре 2016 года). Три коровы красно - пестрой породы с инвентарными номерами KZ F1 96221624/ KZ F1 90710507/ KZ F1 92710521. принадлежащие клинике Аграрного факультета ГУ имени Шакарима. При выявлении причин эндометритов у коров учитывались условия содержания, ухода за животными, качество кормов.

Коровы имели среднюю упитанность, находились в одинаковых условиях содержания и кормления.

Исследование проводилось в зимнее стоиловый период. Кровы размещены в клиническом корпусе стационаре на 15 скотомест, на деревянном настиле. Вдоль каждого ряда расположены кормушки. Животные содержатся на привязи, подстилка - опилки. Раздача кормов в ручную, поение производится из автопоилок. Навозоудаление производится в ручную. Вентиляция приточновытяжная. Относительная влажность около 70\%, температура колеблется в пределах от +2 до +10 . Моцион присутствует.

У коров первой групп поступивших на лечение наблюдались следующие клинические признаки:

- признаки болезни появлись на третьи-шестые сутки после отела. В первые дни болезни у коров уменьшились выделения лохий из матки, ухудшилось общее состояние, снизилась продуктивность. Временами 
коровы принимали позу мочеиспускания, долго стояли с приподнятым хвостом. Слизистая преддверия влагалища, шейки матки, влагалища отечная, покрасневшая;

- при ректальном исследовании матка прощупывается в форме переполненного мочевого пузыря, свешивающегося в брюшную полость. Стенки матки утолщены и дряблые. Матка болезненна и флюктуирует. Во время массажа матки выделение содержимого увеличивается.

- Клинические данные наблюдения

Таблица 2.

\begin{tabular}{|c|c|c|c|r|r|r|r|r|r|r|r|}
\hline $\begin{array}{c}\text { Дата } \\
\text { (декабрь })\end{array}$ & 15 & 16 & 17 & 18 & 19 & 20 & 21 & 22 & 23 & 24 & 25 \\
\hline Температура & 41,2 & 41,3 & 41,0 & 39,8 & 39,9 & 39,6 & 39,2 & 38,5 & 38,4 & 38,4 & 38 \\
\hline Пульс & 82 & 80 & 84 & 80 & 78 & 72 & 68 & 64 & 62 & 60 & 62 \\
\hline Дыхание & 36 & 38 & 38 & 36 & 36 & 35 & 33 & 31 & 28 & 24 & 23 \\
\hline
\end{tabular}

При учете анамнестических данных, клинических признаков и анализу крови был поставлен диагноз - острый послеродовой эндометрит.

Была разработана следующая схема лечения № 1 (таблица 1):

Таблииа 1.

\begin{tabular}{|c|c|c|c|c|c|c|c|c|c|c|c|c|c|}
\hline \multirow[b]{2}{*}{$\begin{array}{c}\text { Наименование } \\
\text { препарата }\end{array}$} & \multirow[b]{2}{*}{ Способ введения } & \multirow[b]{2}{*}{ Доза } & \multicolumn{11}{|c|}{ Дни лечения (декабрь,2015г.) } \\
\hline & & & 15 & $\begin{array}{l}1 \\
6\end{array}$ & $\begin{array}{l}1 \\
7\end{array}$ & $\begin{array}{l}1 \\
8\end{array}$ & $\begin{array}{l}1 \\
9\end{array}$ & $\begin{array}{l}2 \\
0\end{array}$ & $\begin{array}{l}2 \\
1\end{array}$ & $\begin{array}{l}2 \\
2\end{array}$ & $\begin{array}{l}2 \\
3\end{array}$ & $\begin{array}{l}2 \\
4\end{array}$ & $\begin{array}{l}2 \\
5\end{array}$ \\
\hline $\begin{array}{c}\text { Фуразолидоновые } \\
\text { палочки }\end{array}$ & Внутриматочно & 6 шт & + & + & + & + & + & & & & & & \\
\hline Окситоцин & Внутримышечно & 40Ед & + & & + & & + & & + & & + & & + \\
\hline Тетравит & Внутримышечно & 10мЛ & + & & & & & + & & & & + & \\
\hline $\begin{array}{c}\text { Раствор } \\
\text { перманганата калия }\end{array}$ & Внутриматочно & 2,5 л & + & + & + & + & + & & & & & & \\
\hline Бициллин 3 & Внутримышечно & 1фл. & + & & & + & & & + & & & + & \\
\hline
\end{tabular}

У животных этой группы выздоровление наступило: у коровы с инвентарным номером KZ F1 89199650 на 11 сутки, у коров с инвентарными номерами KZ F1 93697212/ KZ F1 95220815 на 9 и 10 сутки

По окончанию курации, и на основании клинических исследований наблюдается выздоровление животного.

Клиническое состояние животного хорошее, животное хорошо принимает корм, слизистая оболочка матки умеренно влажная, истечениий, наложений, кровоизлияний не отмечено. В дальнейшем животному рекомендуется в течении недели проводить активный моцион. Назначить животному щадящий режим содержания, давать с кормом витаминно-минеральные добавки, премиксы.

Таким образом, при проведении эксперимента мы установили что данная схема достаточно эффективна, но требует более длительного курса лечения.

У животных второй группы исследование проводилось в зимнее стоиловый период. Кровы также размещены в стационаре клинического корпуса на 15 скотомест, на деревянном настиле. 
У коров поступивших на лечение наблюдались следующие клинические признаки:

Выделение слизистого экссудата, матка увеличена в размера, отмечается болезненность при пальпации, снижение сократительной фунции.

Наблюдается уменьшение аппетита, легкая угнетенность, лихорадка. У животных из половых путей выделяется мутная, вязкой консистенции слизь, содержащая хлопьевидные включения гноя.

Таблица 3

Клинические даннье наблюдения

\begin{tabular}{|l|l|l|l|l|l|l|l|}
\hline $\begin{array}{c}\text { Дата } \\
\text { (ноябрь,2016) }\end{array}$ & 7 & 8 & 9 & 10 & 11 & 12 & 13 \\
\hline Температура & 41,3 & 40,1 & 39,9 & 39,6 & 39,0 & 38,5 & 38,1 \\
\hline Пульс & 82 & 77 & 73 & 75 & 70 & 68 & 64 \\
\hline Дыхание & 37 & 36 & 34 & 30 & 28 & 26 & 25 \\
\hline
\end{tabular}

При учете анамнестических данных и клинических признаков был поставлен диагноз - острый послеродовой эндометрит.

Основные поставленные задачи:

1) своевременное удаление экссудата из полости матки;

2) подавление жизнедеятельности патогенной микрофлоры во всех участках генитального аппарата;

3) восстановление тонуса и сократительной способности мускулатуры матки;

4) ускорение регенерации поврежденного эндометрия;

5) повышение защитных сил организма;

6) возобновление секреторной функции слизистых оболочек;

7) предотвращение интоксикации продуктами деятельности микробов.

Для того чтобы реализовать поставленные нами цели, на этот раз было решено применить новую схему лечения, которая позволит сократить длительность курса лечения, благодаря чему эта схема лечения является экономическо выгодной.

Новая схема лечения предусматривает использование более новых препаратов, среди которых преобладают витаминные медикаменты, следовательно, у коров повышаются иммунные процессы, что способствует лучшему сопративлению организма патогенной микрофлоре, тем самым выздорвление животного происходит в более короткие сроки.

С этой точки зрения мы применили Гонавет Вейкс и Йодопен

Была разработана следующая схема лечения № 2:

\begin{tabular}{|c|c|c|c|c|c|c|c|c|c|}
\hline \multirow{2}{*}{$\begin{array}{c}\text { Наименование } \\
\text { препарата }\end{array}$} & \multirow{2}{*}{ Способ введения } & \multirow{2}{*}{ Доза } & \multicolumn{7}{|c|}{ Дни лечения (ноябрь, 2016г.) } \\
\hline & & & 7 & 8 & 9 & 10 & 11 & 12 & 13 \\
\hline Иодопен & Внутриматочно & 6 шт & + & + & + & + & + & + & \\
\hline Гонавет Вейкс & Внутримышечно & 2 мл & ++ & ++ & ++ & & & & \\
\hline Тетравит & Внутримышечно & 10мл & + & & & & & + & \\
\hline
\end{tabular}




\begin{tabular}{|c|c|c|c|c|c|c|c|c|c|}
\hline $\begin{array}{c}\text { Раствор } \\
\text { перманганата калия }\end{array}$ & Внутриматочно & $2,5 л$ & + & + & + & + & + & & \\
\hline Бициллин 3 & Внутримышечно & 1 фл. & + & & & + & & & + \\
\hline
\end{tabular}

Чтобы подавить развитие микробов, в полость матки вводят

гинекологические свечи йодопен (6 шт.). с 1 по 6 дни.

Гонавет Вейкс внутримышечно по 2 мл, 2 раза в день на 1, 2, 3 дни.

Тетравит внутримышечно в дозе 10 мл. на 1, 6 день.

Промывание матки с помощью кружки Эсмарха водным раствором перманганата калия 0,1\% на 1 - 5 дни по 2,5 литра.

Внутримышечно на 1, 4, 7 дни вводили бициллин 3 по 1 флакону на изотоническом растворе $0,9 \%$. [7].

У животных этой группы выздоровление наступило:

У коровы с инвентарным номером KZ F1 89199650 на 5 сутки, у коров с инвентарными номерами KZ F1 93697212/ KZ F1 95220815 на 6 сутки

По оканчанию курса лечения у коров отмечается полное выздоровление с последующим приходом в физиологическую норму. В дальнейшем животному рекомендуется в течении недели проводить активный моцион. Назначить животному щадящий режим содержания, давать с кормом витаминноминеральные добавки, премиксы.

Таблица 5

\begin{tabular}{|c|c|c|c|c|c|c|c|c|c|c|c|c|c|}
\hline \multirow{2}{*}{$\begin{array}{c}\text { Наименова } \\
\text { ние } \\
\text { препарата }\end{array}$} & \multirow[b]{2}{*}{$\begin{array}{c}\text { Способ } \\
\text { введения }\end{array}$} & \multirow[b]{2}{*}{ Доза } & \multicolumn{11}{|c|}{ Дни лечения (ноябрь, 2016г.) } \\
\hline & & & 16 & 17 & 18 & 19 & 20 & 21 & 22 & 23 & 24 & 25 & $\begin{array}{l}2 \\
6 \\
\end{array}$ \\
\hline Эстрофан & $\begin{array}{c}\text { Внутримыше } \\
\text { чно }\end{array}$ & 2 мл & + & & & & & & & & & & + \\
\hline
\end{tabular}

Так, как эстрофан оказывает лютеолитическое действие на желтое тело яичников, снимает тормозящее действие прогестерона на гипоталамогипофизарный комплекс вследствии этого введение препарата способствовало росту фолликулов в яичниках и, как следствие этого, увеличению уровня эстрогенов в крови, появлению половой охоты и последующей овуляции созревших фолликулов.

Таким образом, при проведении эксперимента мы установили, что схема лечения № 2 более эффективна, чем схема № 1, ранее используемая для лечения коров. Вследствии применения эстрофана у коров наступило скорейшее возобновление воспроизводительной функции. 


\section{Литература}

1. А.П. Студенцов, В.С. Шипилов, В.Я. Никитин, М.Г. Миролюбов «Ветеринарное акушерство, гинекология и биотехника размножения» 2004 г. Стр. 130-138

2. Джуланов М.Н. «Мал акушерлігі, гинекологиясы және көбею биотехнологиясы» 1996г. Стр. 53-59

3. Иоцюс, Г. Регуляция полового цикла сельскохозяйственных животных / Г. Иоцюс, Г. Шилинкас, Р. Джиачус, С. Будвитис // Животноводство. - 1981.-№4.- С.53-54.

4. Джакупов, И.Т. Показатели воспроизводительной функции коров в зависимости от способов осеменения / И.Т. Джакупов, М.Ш. Аубакиров // Ветеринария. - 2005. - №4. C. 33-34.

5. Петров А.Н., Мирзахметов Ш.Р. Разработка эффективного метода лечения коров при эндометрите. /Ветеринария № 5. - 2006. -с 37-39.

6. Чередков С.Н. и др. Лечение острых послеродовых эндометритов у коров / Вет. наука по производству.—- Минск: Беларусь, 1983. — с. 20.

7. Справочник ветеринарных препаратов. Биологическая фирма "Компонент"

8. Cohen CR, Manhart LE, Bukusi EA, et al. (March 2002). "Association between Mycoplasma genitalium and acute endometritis". Lancet. p. 359 